J. Clin. Chem. Clin. Biochem.

Vol. 14, 1976, pp. 515-520

\title{
Identification and Partial Characterization of Specific Oestrogen-Binding Components in Human Kidney
}

By H. Bojar, K. Balzer, R. Dreyfürst, W. Staib

Institut für Physiologische Chemie II, Universität Düsseldorf

and J. L. Wittliff

Department of Biochemistry, University of Rochester (N. Y.)

(Received April 28/July 23, 1976)

Summary: In normal human kidney from adult males cytoplasmatic components which bound $17 \beta$-oestradiol specifically and with high affinity were demonstrated by dextran-coated charcoal assay, sucrose gradient centrifugation and agar gel electrophoresis. The dissociation constant of the oestradiol-binder complex amounted to $2.2 \pm 0.1 \times 10^{-9}$ $\mathrm{mol} / \mathrm{l}$. The binding capacity was limited to $34.0 \pm 9.7 \mathrm{fmol} / \mathrm{mg}$ of cytosol protein. Sedimentation in sucrose gradient revealed the bulk of these components to be in the $4 \mathrm{~S}$ region. The binding entities could be clearly separated from sex hormone-binding globulin by agar gel electrophoresis. The ligand specificity for binding to these components indicated a requirement for oestrogens. The fact that an excess of aldosterone had no competitive effect on oestradiol binding suggests that the oestrogen-binding sites are independent of mineralocorticoid receptors. It is concluded that the specific binding components in human kidney have the properties of oestrogen receptors.

\section{Identifizierung und teilweise Charakterisierung spezifisch östrogenbindender Komponenten in der menschlichen Niere}

Zusammenfassung: In normalen menschlichen Nieren erwachsener männlicher Patienten wurden mittels Kohle-Adsorptionstechnik, Sucrose-Dichtegradientenzentrifugation und Agargelelektrophorese zytoplasmatische Komponenten nachgewiesen, die 17 $\beta$-Östradiol spezifisch und mit hoher Affinität binden. Die Dissoziationskonstante des ÖstradiolBinderkomplexes betrug 2,2 $\pm 0,1 \times 10^{-9} \mathrm{~mol} / \mathrm{l}$. Die Bindungskapazität war begrenzt und belief sich auf $34,0 \pm 9,7$ $\mathrm{fmol} / \mathrm{mg}$ Cytosolprotein. Bei der Sucrose-Dichtegradientenzentrifugation sedimentierte der größte Teil dieser Komponenten in der 4S-Region. Durch Agargelelektrophorese konnten diese Komponenten klar von sexualhormonbindendem Globulin getrennt werden. In Kompetitionsexperimenten konnte gezeigt werden, daß diese Komponenten spezifisch Ösțrogene binden. Dạ eị ựberschuß an Aldosteron keinen kompetitiven Effekt auf die Bindung von 17 $\beta$-Östradiol hat, sind die östrogenbindenden Komponenten nịcht mit Mineralcorticoidgrezeptoren identisch. Die Untersuchungen zeigen, daß die östrogenbindenden Komponenten die Eigenschaften von Östrogenrezeptoren aufweisen.

\section{Introduction}

Although the kidney is not generally regarded as one of the oestrogen target organs, the induction of hamster kidney tumors by prolonged oestrogen administration is well-known $(1,2)$. One of the reasons for the paucity of information on the oestrogen responsiveness of kidney is the former paradoxical failure to demonstrate oestrogen receptors in normal hamster kidney (3). However, there are some indications of oestradiol binding to cytosol macromolecules and the nuclear fraction of rat kidney $(4,5)$. Moreover, oestrogens have been shown to decrease renal sodium excretion in adrenalectomized rats (4), dogs (6), and normal humans (7). These studies prompted an examination of normal human kidney for oestrogen-binding components. A partial characterisation of these binding sites is presented in this paper. Portions of these data have been reported in a preliminary form (8). 


\section{Materials and Methods}

\section{Chemicals and Reagents}

$\left[2,4,6,7-{ }^{3} \mathrm{H}\right]$ oestradiol-17 $\beta(110 \mathrm{Ci} / \mathrm{mmol})$ and Omnifluor were purchased from New England Nuclear. Unlabelled hormones were obtained from Calbiochem. Serva served as a source of Norit A, while Dextran T 500 was purchased from Pharmacia. Agar purum and bovine serum albumin were obtained from Behring, Marburg. All other chemicals were commercial preparations of analytical grade.

\section{Patients}

Human kidney tissue used in our studies was obtained through the cooperation of Dr. F. Boeminghaus, Urologische Klinik der Universität Düsseldorf. In 1975 ten male patients, aged 49 to 79, were nephrectomized because of renal cell carcinoma or other reasons. As far as cancer kidneys were concerned, the carcinoma was located only at the upper pole of the kidney. Specimens were taken from those parts of the organ, which, by histological examination, proved to be free of infiltrating cancer tissue.

\section{Handling of Kidney Specimens}

Immediately after nephrectomy, the kidney was perfused with 21 of ice-cold Ca-free Krebs-Ringer phosphate buffer, $\mathrm{pH} 7.4$, in vitro. Specimens of the blood-free kidney were decapsulated and instantly immersed in liquid nitrogen.

\section{Preparation of Kidney Cytosols}

Kidney specimens $(5-10 \mathrm{~g})$, which had been stored in liquid nitrogen prior to use, were placed in ice-cold Tris buffer A (10 mmol/1 Tris- $\mathrm{HCl}, 1.5 \mathrm{mmol} / 1 \mathrm{Na}_{2}$ EDTA, $\mathrm{pH} \mathrm{7.4)} \mathrm{or} \mathrm{Tris}$ buffer B $\left(10 \mathrm{mmol} / 1\right.$ Tris- $\mathrm{HCl}, 1.0 \mathrm{mmol} / 1 \mathrm{Na}_{2}$ EDTA, 0.25 $\mathrm{mol} / \mathrm{l}$ sucrose, $\mathrm{pH} 8.0$ ) and allowed to stand at $3^{\circ} \mathrm{C}$ until thawed. The samples were then minced roughly and stirred gently in the same medium $(1: 10 ; \mathrm{w} / \mathrm{v})$ for $10 \mathrm{~min}$ to ensure the removal of serum contaminants. Subsequently, the washed tissue was blotted and homogenized in a Duall homogenizer with cold Tris buffer A or $\mathrm{B}(1: 3 ; \mathrm{w} / \mathrm{v})$. Finally the homogenate was centrifuged at $105000 \mathrm{~g}\left(3^{\circ} \mathrm{C}\right)$ for $30 \mathrm{~min}$ and the supernatant (cytosol) removed without disturbing the lipid layer.

\section{Dextran-Coated Charcoal Assay}

This assay was a modification of the original method reported by Korenman (9). Cytosols ( $0.2 \mathrm{ml}$ portions), prepared in Tris buffer $B$, were incubated with $0.2-4.0 \mathrm{nmol} / 1\left({ }^{3} \mathrm{H}\right)$ oestradiol- $17 \beta$ for $16 \mathrm{~h}$ at $0-3^{\circ} \mathrm{C}$ either alone or in the presence of unlabelled competitive hormones at $1 \mu \mathrm{mol} / \mathrm{l}$. Details of individual experimental designs are given in the legends to figures and tables. Following the incubation the samples were combined with $0.5 \mathrm{ml}$ of $5 \mathrm{~g} / 1$ Norit A, $0.5 \mathrm{~g} / 1$ Dextran T $500,10 \mathrm{mmol} / 1$ Tris-HCl, $1 \mathrm{mmol} / \mathrm{l} \mathrm{Na} 2$ EDTA, $0.25 \mathrm{~mol} / 1$ sucrose at $\mathrm{pH} 8.0$. The mixture was incubated at $0-3^{\circ} \mathrm{C}$ for $5 \mathrm{~min}$ and then centrifuged at $12000 \mathrm{rev} . / \mathrm{min}$ for $2 \mathrm{~min}$ in an Eppendorf centrifuge, model 3200 . Portions $(0.2 \mathrm{ml})$ of the supernatant fluid were transferred into scintillation vials containing $10 \mathrm{ml}$ of Bray's scintillation fluor (10) for counting in a liquid scintillation counting system.

\section{Sucrose Gradient Assay}

The assay procedure closely paralleled that originally described by Toft \& Gorski (11). Briefly, aliquots $(200 \mu \mathrm{l})$ of cytosol prepared in Tris buffer A were reacted with $\left[^{3} \mathrm{H} \mid\right.$ ocstradiol-17 $\beta$ for $2 \mathrm{~h}$ at $0-3^{\circ} \mathrm{C}$, either alone or in the presence of unlabelled competitive hormones at $1 \mu \mathrm{mol} / 1$. Portions $(500 \mu \mathrm{l})$ of $5 \mathrm{~g} / \mathrm{l}$ Norit A, $0.5 \mathrm{~g} / 1$ Dextran T $500,10 \mathrm{mmol} / 1$ Tris- $\mathrm{HCl}, 1.5 \mathrm{mmol} / \mathrm{l}$ $\mathrm{Na}_{2}$ EDTA at pH 7.4 were centrifuged $2 \mathrm{~min}$ at $12000 \mathrm{rev} . / \mathrm{min}$ in an Eppendorf centrifuge. The supernatants were discarded. The labelled cytosols were then mixed with the charcoal pellets and processed as described under dextran-coated charcoal assay. The supernatant fluids were assayed for receptor activity by layering over linear $50-200 \mathrm{~g} / \mathrm{l}$ sucrose gradients in Tris buffer A. These gradients were centrifuged in a Beckman L2-65B preparative ultracentrifuge for $16 \mathrm{~h}$ at $56000 \mathrm{rev} . / \mathrm{min}\left(0^{\circ} \mathrm{C}\right)$, using a Spinco
SW56 titanium rotor. After centrifugation the bottom of the tubes were pierced and six-drop fractions collected into scintillation vials containing $2 \mathrm{ml}$ of $99 \%$ ethanol. Ten milliliters of toluene scintillation cocktail ( $4 \mathrm{~g}$ Omnifluor/1 toluene) were added to each fraction and radioactivity was measured.

\section{Protein Determination}

Protein was estimated by Lowry's method (12), using bovine serum albumin as standard.

\section{Agar Gel. Electrophoresis}

Electrophoresis closely paralleled that originally described by Wagner (13). Briefly, kidney specimens $(1-2 \mathrm{~g})$, which had been stored in liquid nitrogen, were pulverized in three volumes of Tris buffer $\mathrm{C}\left(10 \mathrm{mmol} / 1 \mathrm{Tris}-\mathrm{HCl}, 1.0 \mathrm{mmol} / \mathrm{I} \mathrm{NaN}_{3}, \mathrm{pH} 7.5\right)$ in a mortar chilled with liquid nitrogen. The powder was allowed to thaw at $4{ }^{\circ} \mathrm{C}$. Subsequently, the thawed homogenate was centrifuged at $105000 \mathrm{~g}\left(3^{\circ} \mathrm{C}\right)$ for $30 \mathrm{~min}$ in order to prepare the cytosol. Cytosols $(0.2 \mathrm{ml}$ portions) were incubated for $2 \mathrm{~h}$ at $0-3^{\circ} \mathrm{C}$ with $2 \mathrm{n} \mathrm{mol} / 1$ [ $^{3} \mathrm{H}$ ]oestradiol-17 $\beta$ either alone or in the presence of unlabelled competitive hormones at $1 \mu \mathrm{mol} / \mathrm{l}$. Following the incubation, $50 \mu$ portions of the cytosols were placed into each of the 10 sample wells punched at the centre line of the agar slab. During electrophoresis $(130 \mathrm{~mA}, 70 \mathrm{~min})$ the temperature in the receptor region of the gel was continuously monitored by an epoxycoated extra small thermistor (Yellow Springs Instrument Co., part 44202) and maintained at $3-4^{\circ} \mathrm{C}$ by cooling of the teflon-coated brass block. After the run, the individual analyses were separated by lengthwise slicing the gel slab. Subsequently, the strips were cut into $0.5 \mathrm{~cm}$ sections, using a razor blade. The samples were placed into wire-gauze baskets coated with a thin layer of black paper. The strips were dried at $60^{\circ} \mathrm{C}$ for $12 \mathrm{~h}$. Using special sample hoiders attached to screw caps (BF-Vertriebs GmbH für Meßtechnik, Karlsruhe), the baskets were placed into glass scintillation counting vials, containing $0.5 \mathrm{ml}$ of distilled water. With the aid of a simple device, up to 40 vials were evacuated and filled with oxygen (14). The screw caps were then sealed gas-tight, and automatic in-vial combustion started using the Micro-Mat BF 5010 (BF-Vertriebs $\mathrm{GmbH}$ ). This procedure is a modification of the technique originally described by Gupta (15). When combustion of the samples was complete the vials were allowed to stand at $-10^{\circ} \mathrm{C}$ for about $5 \mathrm{~min}$ in order to completely condense the tritium water-vapor. The special sample holders were removed, $10 \mathrm{ml}$ of Bray's scintillation fluor (10) was added to each vial, the samples being ready for liquid scintillation counting.

\section{Results}

\section{Use of the Dextran-Coated Charcoal Assay}

The charcoal adsorption assay was used to estimate the affinity of the binding components for 17. $\beta$-oestradiol and to determine the ligand specificity of oestradiol binding to these components.

\section{Titration of the cytosol with 17ß-oestradiol}

To ascertain the affinity of the cytoplasmic binder for the hormone, a constant volume of cytosol from human kidney was titrated with increasing concentrations of $\left[{ }^{3} \mathrm{H}\right]$ oestradiol:17 $\beta$. Parallel titrations in the presence of an excess of unlabelled hormone allowed the correction of the binding data for non-specific binding. Using the method of Scatchard (16), a typical analysis of the titration data shown in Figure 1 resulted in a straight line. From the slope of the Scatchard plot the dissociation 


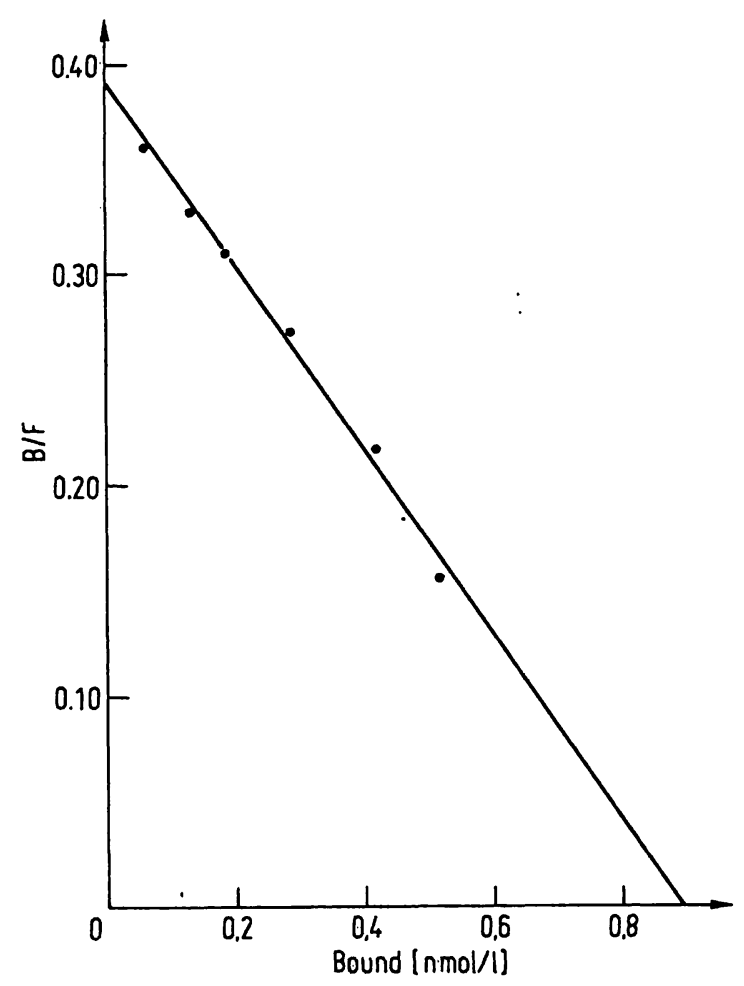

Fig. 1. Scatchard analysis of titration data for the oestrogenbinding components in the cytosol of human kidney. Cytosols $(0.2 \mathrm{ml}$ portions) prepared in Tris buffer B were incubated with increasing concentrations of $\left[{ }^{3} \mathrm{H}\right]$ oestradiol- $17 \beta(0.2-3.7 \mathrm{nmol} / \mathrm{l})$ at $0-3^{\circ} \mathrm{C}$ for $16 \mathrm{~h}$ either alone or in the presence of unlabelled oestradiol at $1 \mu \mathrm{mol} / \mathrm{l}$. Binding was measured by dextran-coated charcoal assay. $\mathrm{K}_{\mathrm{d}}=2.2 \cdot 10^{-9} \mathrm{~mol} / \mathrm{l}$.

constant $\left(\mathrm{K}_{\mathrm{d}}\right)$ of the binder-ligand complex was calculated and found to be $2.2 \pm 0.1 \times 10^{-9} \mathrm{~mol} / 1$ (mean \pm SEM of five individual experiments). The concentration of binding sites, assuming that each site binds only one molecule of $17 \beta$-oestradiol and that only a single class of binding entities exists, amounted to $34.0 \pm 9.7 \mathrm{fmol} / \mathrm{mg}$ of cytosol protein (mean \pm SEM of five individual experiments), ranging from 10 to $60 \mathrm{fmol} / \mathrm{mg}$ of protein.

\section{Ligand specificity}

The relative affinities of several steroid hormones for the $17 \dot{\beta}$-oestradiol binding components, as measured by competition studies, are summarized in Table 1 . The ligand specificity for binding to these sites clearly indicated a requirement for oestrogens. The binding of tritiated $17 \beta$-oestradiol was inhibited by unlabelled $17 \beta$-oestradiol as well as by oestrone and oestriol. Aldosterone and cortexolone were only insignificantly competitive with $17 \beta$-oestradiol for binding sites in human kidney cytosol. All other steroịds tested were not competitive.

\section{Sucrose Gradient Centrifugation}

Sedimentation patterns of the $17 \beta$-oestradiol binding entities of human kidney cytosol on sucrose density gradients are shown in Figure 2. Specific binding is in-
Tab. 1. Ligand specificity of $\left[{ }^{3} \mathrm{H}\right]$ oestradiol-17 $\beta$ binding assessed by dextran-coated charcoal assay and agar gel electrophoresis of cytosol from human kidney.

Dextran-coated charcoal assay - Cytosols $(0.2 \mathrm{ml}$ portions) prepared in Tris buffer $B$ were incubated with $3.7 \mathrm{nmol} / 1\left[^{3} \mathrm{H}\right]$ oestradiol $-17 \beta$ for $16 \mathrm{~h}$ at $0-3^{\circ} \mathrm{C}$ either alone or in the presence of a competitive substance at $1 \mu \mathrm{mol} / \mathrm{l}$. Each reaction was terminated by the addition of $0.5 \mathrm{ml}$ of the dextran-coated charcoal reagent.

Agar gel clectrophoresis - Aliquots $(0.2 \mathrm{ml})$ of cytosol, prenared in Tris buffer $C$, were incubated with $2 \mathrm{nmol} / 1$ $\left.i^{3} \mathrm{H}\right]$ oestradiol-17 $\beta$ for $2 \mathrm{~h}$ at $0-3^{\circ} \mathrm{C}$, either alone or in the presence of unlabclled hormones at $1 \mu \mathrm{mol} / \mathrm{l}$. Conditions of agar gel electrophoresis: $50 \mu \mathrm{l}$ portions of reacted cytosol applied to $10 \mathrm{~g} / \mathrm{l}$ agar gel, $130 \mathrm{~mA}, 70 \mathrm{~min}, 3-4^{\circ} \mathrm{C}$ (gel temperature in receptor region), $5 \mathrm{~mm}$ sections counted after in-vial combustion.

Inhibition of specific $\left.\right|^{3} \mathrm{H}$ |oestradiol-17 $\beta$ binding is expressed as a percentage of control value.

\begin{tabular}{lcc}
\hline Competitive Substance & $\begin{array}{l}\text { Inhibition of Specific }\left[{ }^{3} \mathrm{H} \text { OOestradiol- }\right. \\
17 \beta \text { Binding }[\%] \\
\text { Dextran-Coated } \\
\text { Charcoal Assay }\end{array}$ & $\begin{array}{l}\text { Agar Gel } \\
\text { Electrophoresis }\end{array}$ \\
\hline None & 0 & 0 \\
Oestradiol & 100 & 100 \\
Oestrone & 95 & 100 \\
Oestriol & 95 & 100 \\
Progesterone & $<1$ & $<1$ \\
Testosterone & $<1$ & - \\
Dihydrotestosterone & $<1$ & $<1$ \\
Cortisol & $<1$ & $<1$ \\
Dexamethasone & - & $<1$ \\
Corticosterone & $<1$ & - \\
Cortexolone & 3 & $<1$ \\
Aldosterone & 5 & $<1$ \\
\hline
\end{tabular}

dicated by the difference in the areas under the peaks, obtained in the absence (closed circles) or presence (open circles) of an excess of unlabelled 17 $\beta$-oestradiol. Analysing the cytosols from kidneys of different patients, two distinct types of isotopic profiles were obtained. In both plots (Figure 2, profile A and profile B) specific binding of $17 \beta$-oestradiol to a macromolecular component, sedimenting in the $4 \mathrm{~S}$ region of the gradient, could be detected. However, in profile A, additional specific binding entities at about $3 \mathrm{~S}$ and $6 \mathrm{~S}$ were discernible. Moreover, a significant fraction of the radioactivity was recovered at the bottom of the centrifuge tube, thus showing a considerable higher sedimentation coefficient. It therefore appears that in some cases at low salt concentration 17 $\beta$-oestradiol forms a complex with cytosol macromolecules which tend to aggregate:

\section{Agar Gel Electrophoresis}

In order to more closely characterize the oestrogen binding components in human kidney, the cytosol was applied to agar gel electrophoresis at low temperature. The assay discriminates between receptor proteins and sex hormone-binding globulin which might be present in human tissue extracts due to serum contamination (13). 

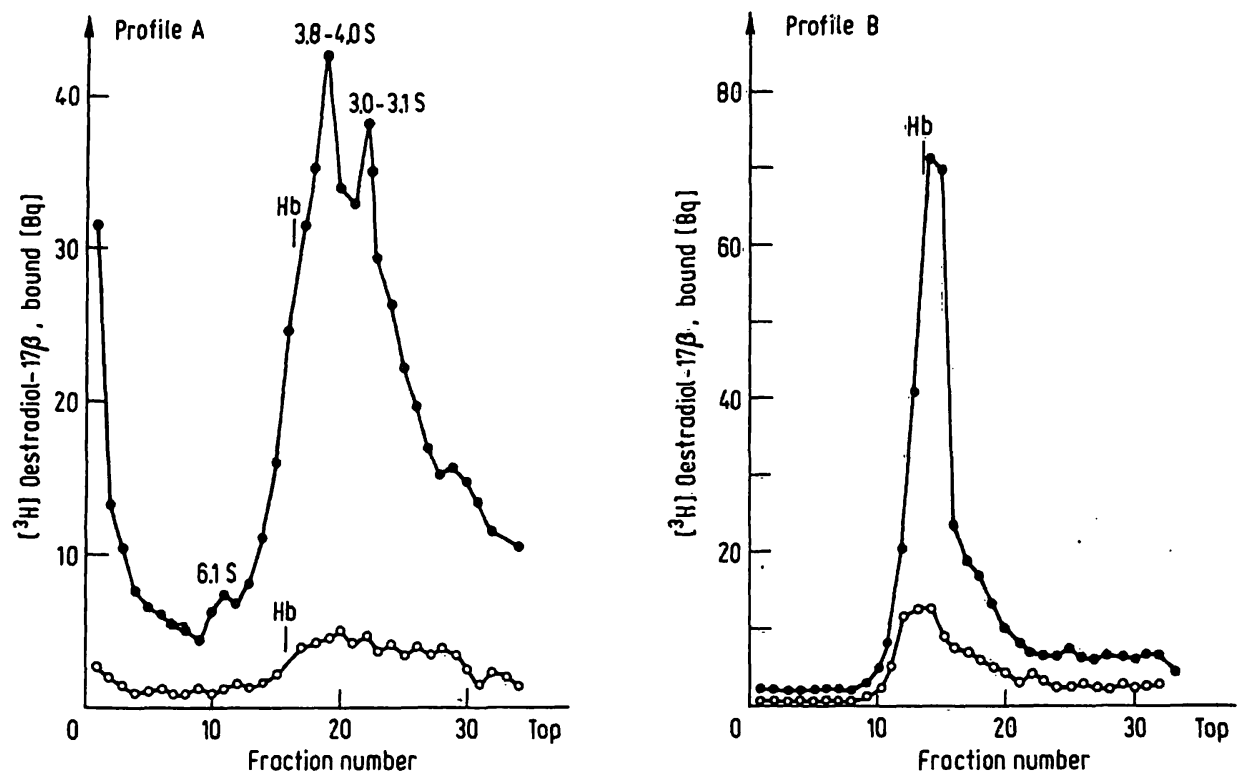

Fig. 2. Two representative types of isotopic profiles of oestrogen-binding components separated by sucrose gradient centrifugation of cytosols obtained from human kidneys. Aliquots $(0.2 \mathrm{ml})$ of cytosol prepared in Tris buffer A were incubated in vitro with $3 \mathrm{nmol} / 1{ }^{3} \mathrm{H}$ ]oestradiol-17 $\beta$ for $2 \mathrm{~h}$ at $0-3^{\circ} \mathrm{C}$, either alone (closed circles) or in the presence of unlabelled $17 \beta$-oestradiol at $1 \mu \mathrm{mol} / \mathrm{l}$ (open circles). The cytosols were subjected to dextran-coated charcoal treatment and then assayed for binding activity by layering over linear $50-200 \mathrm{~g} / \mathrm{l}$ sucrose gradients in Tris buffer $A$. The gradients were centrifuged for $16 \mathrm{~h}$ at $56.000 \mathrm{rev} . / \mathrm{min}$ $\left(0^{\circ} \mathrm{C}\right)$, using a Spinco SW 56 rotor.

Isotopic profiles of the oestrogen binding entities separated by agar gel electrophoresis of human kidney cytosol are shown in Figure. 3. As estimated by the difference between the isotopic profiles of total (open circles) and non-specific binding (closed circles) specific binding of $\left[{ }^{3} \mathrm{H}\right]$ oestradiol- $17 \beta$ could be demonstrated in the receptor region of the gel. No appreciable amounts of sex hormonebinding globulin which migrates towards the cathode are to be seen in this plot. The ligand specificity of $\left[{ }^{3} \mathrm{H}\right]$ oestradiol-17 $\beta$ binding in the receptor region, as measured by competition studies in the presence of a hundred-fold excess of unlabelled hormone is summarized in Table 1. The results are very similar to those assessed by the dextran-coated charcoal procedure. The ligand specificity for binding to molecules in the receptor region indicated a stringent requirement for oestrogens. Essentially no inhibition of $\left[{ }^{3} \mathrm{H}\right]$ oestradiol- $17 \beta$ binding was observed in the presence of all other steroid hormones tested.

\section{Discussion}

Evidence was obtained for the existence of specific binding sites for oestrogens in human kidney cytosol. The fact that unlabelled aldosterone did not significantly compete with tritiated $17 \beta$-oestradiol for binding to these entities indicates that the oestrogen-binding sites are independent of mineralocorticoid receptors. These findings are supported by similar observations of the ligand specificity of oestradiol binding by rat kidney cytosol $(4,5)$. The inability of dihydrotestosterone and glucocorticoid hormones, to compete with oestradiol for binding to

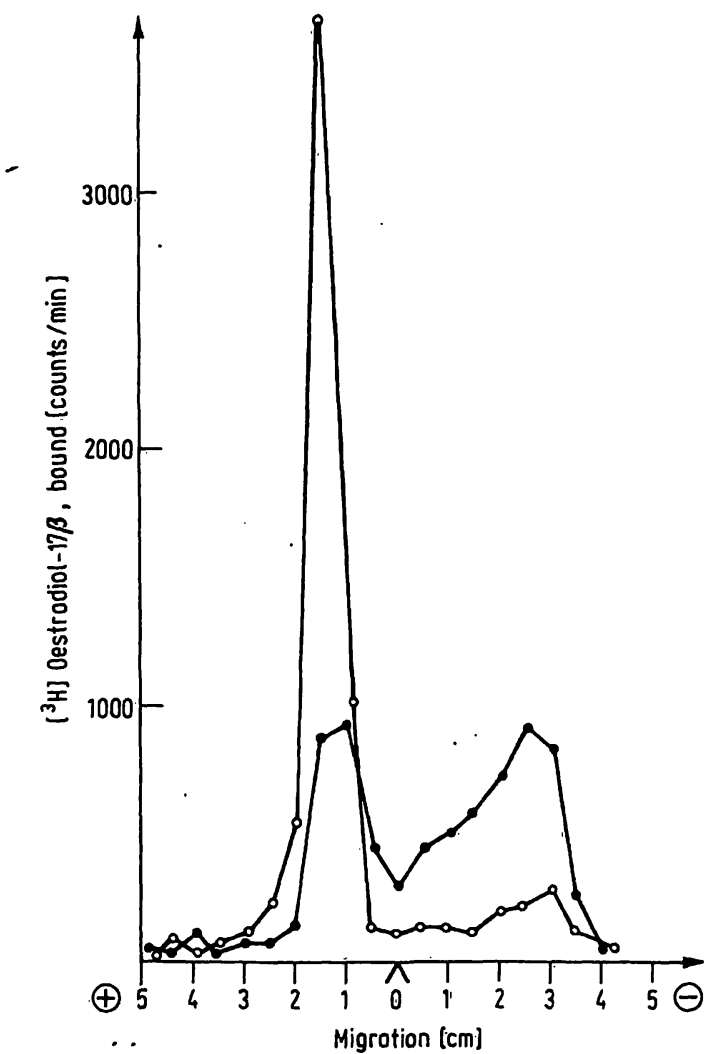

Fig. 3. Isotopic patterns of oestrogen-binding components separated by agar gel electrophoresis of cytosols obtained from human kidney. Cytosols $(0.2 \mathrm{ml})$ prepared in Tris buffer C were reacted in vitro with $\left.2 \mathrm{nmol} / 11^{3} \mathrm{H}\right]$ oestradiol-17. $\beta$ for $2 \mathrm{~h}$ at $0-3^{\circ} \mathrm{C}$, either alone (open circles) or in the presence of a 100 -fold excess of unlabelled $17 \beta$-oestradiol (closed circles). Conditions of agar gel electrophoresis: $50 \mu \mathrm{l}$ portions of labelled cytosol applied to $10 \mathrm{~g} / \mathrm{l}$ agar gel, $130 \mathrm{~mA}, 70 \mathrm{~min}, 3-4^{\circ} \mathrm{C}$ (gel temperature in receptor region), $5 \mathrm{~mm}$ sections counted after in-vial combustion. 
these sites, suggests that the oestrogen-binding components are not identical with androgen or glucocorticoid receptors which have been demonstrated in the kidney of mice (17) and rats (18), respectively. The observation that the binding of oestradiol was unaffected by testosterone (Table 1) made it unlikely that the binding entities were identical with sex hormone-binding globulin which is known to have a high affinity for testosterone (19). Moreover, by agar gel electrophoresis (Fig. 3) it could be clearly demonstrated that the oestrogen binding components from human kidney cytosol exhibited an electrophoretic mobility which was different from that of sex hormone-binding globulin and which closely resembled that of oestrogen receptors in calf uteri (13). The binding reaction displayed saturation kinetics and high affinity binding of $17 \beta$-oestradiol to cytosol macromolecules. Presumptive evidence exists that these high affinity - low capacity sites are most likely to represent receptor complexes from different organs have been found to be in the range of $10^{-12}$ to $10^{-9} \mathrm{~mol} / \mathrm{l}(4,20,21,22)$, but widely varying experimental conditions make quantitative comparisons of little value. However, the dissociation constant of the high affinity binder-ligand complex from human kidney cytosol $\left(\sim 2 \times 10^{-9} \mathrm{~mol} / \mathrm{l}\right)$ is strikingly similar to that of rat kidney $\left(\sim 3 \times 10^{-10}-1 \times 10^{-9}\right.$ $\mathrm{mol} / \mathrm{l})$, rat mammary gland $\left(\sim 8 \times 10^{-10} \mathrm{~mol} / \mathrm{l}\right), \mathrm{R} 3230 \mathrm{AC}$ mammary adenocarcinoma $\left(\sim 1.2 \times 10^{-9} \mathrm{~mol} / \mathrm{l}\right)$, human breast carcinoma $\left(\sim 9 \times 10^{-10} \mathrm{~mol} / \mathrm{l}\right)$ and human renal cell carcinoma $\left(\sim 3 \times 10^{-9} \mathrm{~mol} / \mathrm{l}\right)$ found in our laboratories $(5,21,22,-23)$. The number of high affinity binding sites of human kidney cytosol ( $34 \mathrm{fmol} / \mathrm{mg}$ cytosol protein) compares well with that of rat kidney $(\sim 50 \mathrm{fmol} /$ $\mathrm{mg})(4)$ and lactating mammary gland of the rat ( 15-50 fmol/mg) (21).

Interestingly, the binding capacity of cytosol prepared from different kidney specimens varied considerably
(10-60 fmol/mg of protein), although the dissociation constant of the oestradiol-binder complex remained nearly constant. It is supposed that the oestrogen-binding components of human kidney are not evenly distributed among medulla and cortex. Experiments to determine the distribution of these binding sites are in progress. However, according to preliminary results, the oestradiolbinding sites are found predominantly in the kidney medulla.

By sucrose gradient analysis, two distinct types of sedimentation behaviour were demonstrated (Fig. 2). In both profiles, sedimentation of the binder-ligand complex at about $4 \mathrm{~S}$ was observed, which closely resembles that of unactivated oestradiol receptor complexes in various target organs. Whether the 3.0-3.1 S peak in profile $\mathrm{A}$ (Fig. 2) represents binding to precursors (3.5 S) of the oestrogen receptors (24) remains to be elucidated. So far, no definite explanation can be provided for the absence of high molecular weight aggregates in some sucrose gradient analyses. The finding of oestrogen receptors in human kidney raises the question about their physiological significance. At present, oestrogens seem to be involved in the regulation of renal sodium excretion in various species, including man $(4,6,7)$. Moreover, studies of our own laboratory indicate that $17 \beta$-oestradiol stimulates protein synthesis in enzymatically isolated kidney tubules of rat and man (23).

\section{Acknowledgements}

This investigation was supported by the Minister für Wissenschaft und Forschung des Landes Nordrhein-Westfalen.

\section{References}

1. Kirkman, H. (1959), Nat. Cancer Inst. Monogr. 1, 1-59.

2. Steggles, A. W. \& King, R. J. B. (1968), Europ. J. Cancer 4, $395-401$.

3. Ṡteggles, A. W. \& King, R. J. B. (1972), Europ. J. Cancer 8 , $323-3.34$.

4. De Vries, J. R., Ludens, J. H. \& Fanestiel, D. D. (1972), Kidney International 2, 95-100.

5. Bojar, H., Wittliff, J. L., Balzer, K., Dreyfürst, R. \& Staib, W. (1974), Hoppe-Seyler's Z. Physiol. Chem. 355, 1181.

6. Johnson, J. A., Davis, J. O., Baumber, J. S. \& Schneider, E. G. (1970), Am. J. Physiol. 219, 1691-1697.

7. Preedy, J. R. K. \& Aitken, E. H. (1956), J. Clin. Invest. 35, 423-429.

8. Bojar, H., Wittliff, J. L., Balzer, K., Dreyfürst, R., Boeminghaus, F. \& Staib, W. (1975), Acta Endocr. (Kbh) Suppl. 193, 51.

9. Korenman, S. G. (1968), J. Clin. Endocrinol. Metab. 28, 127-130.

10. Bray, G. A. (1961), Anal. Biochem. 1, 279-285.
11. Toft, D. \& Gorski, J. (1966), Proc. Nat. Acad. Sci. U.S. 55, $1574-1581$.

12. Lowry, O. H., Rosebrough, A. L., Farr, A. L. \& Randall, R. J. (1951), J. Biol. Chem. 193, 265-275.

13. Wagner, R. K. (1972), Hoppe-Seyler's Z. Physiol. Chem. 353, $1235-1245$.

14. Wegner, L. A. \& Winkelmann, H. (1970), Atompraxis 16, 19-26.

15. Gupta, G. N. (1966), Analyt. Chem. 38, 1356-1359.

16. Scatchard, G. (1949), Ann. N.Y. Acad. Sci. 51, 660-672.

17. Drews, U., Itakura, H., Dofuku, R., Tettenborn, U. \& Ohno, S. (1972), Nature New Biol. 238, 216-217.

18. Rafestin-Oblin, M. E., Michaud, A. \& Corvol, P. (1975), 10th Meeting Federation of European Biochemical Societies, Abstract No. 1376.

19. Westphal, U. (1971), Steroid-Protein Interactions (Gross, F., Labhart, A., Mann, T., Samuels, L. T. \& Zander, J., eds.) pp. 356-37.4, Springer-Verlag, Berlin, Heidelberg, New York. 20. Hähnel, R. (1971), Steroids 17, 105-132. 
21. Wittliff, J. L., Gardner, D. G., Battema, W. L. \& Gilbert, P. J. $\quad$ 23. Bojar, H., Dreyfürst, R., Balzer, K., Döscher, D. \& Staib, W. (1972), Biochim. Biophys. Res. Commun. 48, 119-1.25. (1975), Acta Endocr. (Kbh.) Suppl. 199, 130. \& Orlando, R. A. (1972), Cancer Res. 32, 1983-1992. Seyler's Z. Physiol. Chem. 354, 1599-1610.

Dr. Hans Bojar Institut für Physiologische Chemie II der Üniversität Düsseldorf Moorenstraße 5

D-4000 Düsseldorf 